\title{
urnal Teknologi
}

\section{Mediating Impact of Manufacturing Technology , Lean and Strategic Fexibility on Manufacturing Performance}

\author{
Risya wati Mohamed Ismaila* Razli Che Razak b Halim Mad Lazim c \\ a,c School of Technology Management and Logistic, College \\ of Business, University Utara Malaysia, 06010 Sintok, Malaysia \\ ${ }^{b}$ Faculty of Entrepreneurship and Business, Universiti \\ Malaysia Kelantan,Pengkalan Chepa,16100, Kelantan.
}

*Corresponding author: nisyawati@uum.edu.my

\begin{abstract}
In respect of Malaysian lean manufacturer, there has been insufficient research on what are the winning formulae to overcome the mounting challenges from the business environment. In this study, three identified strategies i.e lean, manufacturing technology and strategic flexibility, that could positively improve manufacturing performances, are investigated in depth. The research approach used was quantitative with data analyzed using SmartPLS. Results from this study also emphasize several interesting quasi - paradoxical relationships which implied that Malaysian lean manufacturers prefer a cautious approach towards manufacturing technology implementation, preferring to incorporate technology in a more stable business environment and view strategic flexibility as unfavorable toward performance improvement. In conclusion, this study manages to produce a strong predictive strategy-performance model, which explains the mediation impact of manufacturing strategies on extemal environmental factors and manufacturing performance.
\end{abstract}

Keywords: Lean, manufacturing technology, stra tegic flexibility, performance

\section{ABSTRAK}

Menujuk kepada pengilang lean Malaysia; terdapat kajian yang tidak mencukupi mengenai apakah formula terbaik untuk mengatasi cabaran yang semakin meningkat dari persekitaran pemiagaan. Dalam kajian ini, tiga stra tegi ia itu lean, teknologi pengilangan dan fleksibiliti strategik, dikenal pasti apabila dilihat berpotensi boleh meningkatkan prestasi pengilangan, untuk dikaji secara mendalam. Pendekatan kajian yang digunakan ialah kuantitatif dengan data dianalisis menggunakan SmartPLS. Hasil daripada kajian ini juga menekankan beberapa hubungan kuasi paradoks yang menarik di mana pengilang lean di Malaysia didapati mengambil pendekatan yang lebih berhati-hati ke arah pelaksanaan teknologi pembuatan, lebih suka untuk menggunakan teknologi pengilangan dalam persekitaran pemiagaan yang lebih stabil dan melihat fleksibiliti strategik sebagai tidak menyumbang ke arah peningkatan prestasi. Kesimpulannya, kajian ini berjaya menghasilkan model stra tegi ramanlan prestasi yang mantap, yang menerangkan kesan pengantaraan strategi pembuatan terha dap hubungan antara faktor persekitaran lua ran dan prestasi pengeluaran.

Kata kunci : Lean , teknologi pembua tan, fleksibiliti stra tegik, prestasi 


\subsection{INTRODUCTION}

Malaysia's development has been largely fuelled by export-led growth. However, globalization has increasingly intensified competition and has sharpened the distinction between victors and losers. As a nation, Malaysia is an open economy, which depends heavily on extemal trade to achieve its economic growth $[7,28,75,128,142]$. Given the openness of its economy, the negative wealth effects of the global crisis on demand and world trade have resulted in a decline in Malaysia's industrial production and manufacturing exports. Due to a relatively small population, Malaysia's domestic market is insufficient to finance additional growth for its economy. Consequently, intemational trade has been crucial in the development of the Malaysian economy, and foreign trade has been a significant and substantially increasing portion of the nation's gross domestic product (GDP) over the last

three decades [128]. The findings from a study by [52] suggest that trade is an important variable in promoting economic growth for Malaysia, hence, its exposure to intemational instability is inevitable. Due to such heavy dependence on extemal trade, Malaysia's economy can be considered sensitive to any extemal shocks that could range from economic crises to intensifying global competition.

In the context of this research, the focus remains on the manufacturing sector for several reasons. Firstly, manufacturing has emerged as a leading sector in Malaysia in terms of adopting new operating and quality practices, and these practices are driven prima rily by competitive rather than regulatory forces. Secondly, the industry is heterogeneous in tems of sub-sectors and product/process complexity. Thirdly, manufacturing is a very important sector in Malaysia. According to the Tenth Malaysia Plan 2011-2015, the manufacturing sector contributed $26.7 \%$ to Malaysia's gross domestic product in 2012. Exports from the sector constituted $80.5 \%$ of total merchandise exports. The electrical and electronics $(E \& E)$ industry is the largest single contributor with $26.1 \%$ of manufacturing output, and the largest employer at $40.0 \%$ of total manufacturing labor.

Due to such an important role, the manufacturing sector remains as the major and crucial indicator of the Malaysian economy. Thus, increasing global competition with customers demanding higher product quality, greater product selection, and superior customer service amid rising input costs have led many Malaysian manufacturing companies to adapt, adopt and develop various operational strategies in orderto minimize wastage and defects, to improve product quality, and to sustain profitability and overall perfomance. Manufacturers face an unprecedented force from foreign products, new product introduction by competitors, rapid technological innovation and shorter product life cycle and changes in customer demands [35,47, 133]. To cope with these uncertain environments, manufacturers must continuously examine their strategies, practices, capabilities and identify the impact between these elements and their performance [42,65]. In searching for a new manufacturing paradigm, existing prominent manufacturing practices, such as lean manufacturing, have been chosen by some Malaysian manufacturers to mitigate extemal environmental factors, such as global competition, escalating raw material cost, supply chain variability, intensifying complex and hostile business environment.

However, implementing strategies take a lot more than just adopting a system or a proven strategy. Manufacturing strategy has been broadly defined and a pproached, providing va rious positive altematives for manufacturers, but, at the same time, making the process more complicated and complex. In the current competitive environment, complemented by the advancements in technology, trade agreements and an open market; manufacturing strategy has continued to receive significant and serious attention from researchers. The consensus is that if manufacturers fail to recognize the relationship between manufacturing strategy and their business environment, and how it impacts their perfomance, they will be saddled with a noncompetitive production system that will be costly, rigid and out of date [65, $106,113,135,124]$. Such a predic ament will be fatal for manufactures, preventing them from becoming dynamic enough to respond to any challenge surrounding theiroperations [53]

\subsection{MALAYSIAN MANUFACTURER'S PERFORMANCE}

The influx of foreign products, new product introduction by competitors, shorter product lifecycle, rapid technology updates, and changes in customer demand have forced manufacturers to re-examine their current strategy and achievements [8, 34, 131]. With such a dynamic environment as in Malaysia, manufacturers also face a high level of uncertainty caused by these ongoing changes. The electronics industry, which had been shown earlier as Malaysia's main export eamer since 1974, and the leading contributor of employment, has experienced a performance downtum since 1997. Unlike the experience of Korea and Taiwan where their locally owned fims have driven the catch-up process [10, 11, 98], multinational comorations (MNC) dominated electronics production and exports in Malaysia [99]. Thus, any threat to these overseas corporations would undeniably affect their plants loc ated in Malaysia and any form of recovery plans would be more complicated due to the characteristics of MNCs itself. A similar effect can be observed in the supply chain of these manufacturers due to their global links to their suppliers and vice versa. 
Malaysia is a small country with a small local market, thus heavy dependence on export perfomance is unavoidable. This means that any changes in the global economy will have a more focal and significant impact on the local manufacturers. The downslide of manufacturing performance in Malaysia was in tandem with the decline in the global market shares of exports. In 2009 alone, the Productivity Report posted a massive drop of $8.6 \%$ in terms of total manufacturing productivity due to a deterioration of the electrical and electronic product cluster, which contracted to a share of about $22.8 \%$. Since manufacturing constitutes the largest single component of Malaysia's economy, without doubt, sluggish manufacturing perfomance will also affect the nation'soverall economy.

\subsection{Extemal Environmental Impacts on Malaysian Manufacturers}

Due to the heavy dependence on global trading partners and with the concept of an open market, Malaysian manufacturers cannot avoid being affected by changes in their surrounding environment. Various researches have been conducted to confim this relationship in the context of this country. For instance [128] whom investigated the interdependence of Malaysia's economy on other countries, especially its trading partners using business cycle analysis. In this study, the business cycle concept was studied using two dimensions of cyclical fluctuation - growth rate and growth cycle. Growth rate cycle assumes that the growth rate of an economic indicator is cyclical while growth cycle focuses more on estimating the long-term trend of economic time series. The main objective of this study was to provide evidence for the decoupling hypothesis, and whether Malaysia's economy is influenced by instability in the economies of other nations. One of the observations in this study was the fact that the period of financial instability in the intemational market also coincided with Malaysia's cyclical tums, for example, the evidence conceming the US 2007/2008 debt crisis in which the Malaysian economy was also impacted. However, a nother observation from the same study suggested that Malaysia's economic recession did not anise from the slower demand of advanced economies. Nevertheless, the scholar did note that his finding was only based on judgment rather than the appropriate use of statistical tools and suggested that future research should revisit the issue through the means of statistics.

Another research conceming Malaysia's trade performance in relation to its trade partners was conducted by [75]. Again, this researcheralso pointed out that Malaysia's economy is too sensitive to extemal shocks. One cited incident was during the period from 2000 to 2005, when instability in the US economy played a relatively important role in inducing domestic production and value added strategies for Malaysia.
The findings from this study pointed out that the financial recession of most Asian countries in 1997 affected Malaysia's overall export performance and also caused imports to drop, particularly in relation to the manufacturing sector. Thus, when there was an upswing in 2007, it was associated with the robust global economic recovery and the efforts of the govemment in sending out trade missions to open new markets.

The extent to which extemal environmental factors signific antly impacts manufacturing performance has been empinically documented in previous research. To a large extent, the extemal environmental factors of any organization determine its adopted strategy for reaping the competitive advantage [81,90]. Extemal environmental factors have been empirically proven as crucial elements that affect manufacturing performance. Fims that respond correctly to extemal environment factors and align properly with the firm strategies, perform better $[8,61,124,135]$. In order to be competitive and ensure survival, manufacturers need to respond rapidly to a changing environment [38, 66, 47, 42, 117]. [80] and [42] reported how extemal environmental factors, such as changes in demand, customer requirements and overall uncertainty could have a negative impact on the growth, output, operation and strategies of fims.

\subsection{MANUFACTURING SIRATEGIES}

The link of manufacturing strategies to performance has been discussed by various scholars. The manufacturing strategy determines how manufacturing resources and capabilities are deployed based on the process, content and implementation $[20,54]$. With the progress made from the seminal work of $[54,57,118]$, the conventional manufacturing strategy paradigm has been changing and evolving. Core manufacturing concepts, such as manufacturing practices, capabilities and world class manufacturing process, have been challenged and improved.

\subsection{Lean as a Manufacturing Strategy}

Lean manufacturing has received notable approval among researchers, as being able to improve productivity through a reduction of waste [24, 25], added value to product [123], and basically improving the majority of operational keys, such as the reduction of lead time, better inventory level as well as unit cost $[24,84,136]$, which, in tum, allow improvement against competitors. Regardless of whether the manufacturers make highly differentiated products with a few models or use repetitive configurations, or vary in tems of the industry in which they operate, lean has proven to be superior and beneficial $[40,55,126]$.

The lean strategic approach is based on the assessment of lean as a strategy to improve 
perfomance [5] showing that organizations achieve higher perfomance through the management of their manufacturing strategy. Such an outlook indicates that the complementary aspect between strategy and performance is crucial when pursuing long-term benefit $[17,73,78,122]$. It has been recognized that a strategic approach is necessary in explaining how the practice of lean helps improve performance $[16,127$, 130]. These aforementioned scholars summed up the claim that lean as a strategy can bring significant competitive advantage when it is exploited in the long-term for the development of specific capabilities of the organization.

\subsection{Manufacturing Technology as a Strategy}

Manufacturing technology can be strategically used to achieve a sustainable competitive edge and enables manufacturers to acquire a superior performance position $[70,83]$. The strategic implementation of manufacturing technology allows manufacturers to respond to demand uncertainty and increases their competitive advantage $[44,48]$. Strategic technology choice enables the company to not only focus on the implementation of the technology but also on how effective the investment is toward the perfomance of the manufacturers. From a strategic perspective, manufacturing technology acts as a tool used by fims to adapt and react to the increasingly volatile and complex business environment [95,120]. Another researcher [94], reported that two out of six strategic characteristic of the most successful companies are the willing ness and ability to acquire technology and take technology risks. These strategic advantages are crucial factors that have been noticed and adopted successfully by Japanese manufacturers [95]. The acquisition of appropriate technology is very important to enable a competitive advantage to be gained $[21,46,103]$.

\subsection{Strategic Rexibility as a Strategy}

Strategic flexibility enables the manufacturers to better deal with the dynamic and changing environment and aids them in adopting a strong stance against the threats from competitors [58, 72, 109, 121]. Flexibility has started to occupy a centralized position in how manufacturing could be strategically developed to play an important part in acquiring competitor advantage $[35,49,119]$. Flexibility has been widely defined by different researchers, proving it to be a multifaceted concept. [114] identified at least 50 different definitions of flexibility as of the multitude of facets provided by [49] and [35]. However, consolidation of these ideas fimly points to the importance of flexibility as a 'tool' or prerequisite to effectively respond to changing market needs [13, $18,44]$ and how it enhances perfomance $[32,58,104]$. Strategic flexibility has been viewed by various sc holars namely [60,66, 101] as a crucial factor for global companies in order to compete and survive in an open market, which is also a similar requirement and challenge for Malaysian manufacturers.

\subsection{IMPLEMENTING MULTIPLE STRATEGIES}

Earlier researchers namely $[30,100,135]$ unanimously agreed that fim performance is the consequence of several elements within the fim that integrate and support each other. [135] and [100], all supported the supposition that compatibility a mong such factors, e.g. strategy, structure and technology, would enhance organizational performance. This shows how the implementation of strategy and practices is not a standalone element, but requires compatible addition in order to significantly impact the strategic outcome. Such a requirement might be the reason behind the unsuccessful implementation of lean. The suggestion that lean is not a piecemeal approach is also supported by various lean researchers namely [51,111, $115,116]$. Recent literature often mentions a utomation as part of the strategy that should be incorporated more prominently in lean implementation $[26,53,79]$. Inevitably, in disc ussing the topic of a utomation in lean as a strategy, flexibility comes into perspective. Flexibility has long being linked to manufacturing technology. Fims choose to invest heavily in hard and soft production technology in order to increase their capability to be flexible $[15,19,45,58]$. At the operational level, such an investment will ensure lower machine breakdown, and more product variety, etc., while accumulation of operational flexibility will enable the achievement of strategic flexibility for the firms; a notion supported by [36]. Although lean manufacturing is undoubtedly superior $[3,6,115]$, the low success rate $[12,96,111]$ has resulted in manufacturers and researchers looking for ways to enhance their chosen strategy in order to improve the outcome of their manufacturing performance. From the review of the literature, manufacturing technology and strategic flexibility have a part in making lean work for manufacturers through indirect effects on the performance, thus proposing a multiple mediation relationship.

\subsection{RESEARCH QUESTIONS}

From literature review, the following research questions are derived:

RQ 1 - Do extemal environmental factors (EEF) have an impact on the performance of Malaysian manufacturers?

RQ2 - Do extemal environmental factors have an impact on the implementation of manufacturing strategies, such as manufacturing technology (MT), lean manufacturing (LM) and strategic flexibility (SF)?

RQ3 - Do manufacturing strategies, such as manufacturing technology, lean manufacturing and 
strategic flexibility, have an impact on the Malaysian manufacturing performance (MP)?

RQ4 - Do manufacturing strategies, such as MT, LM and SF, mediate the relationship between EEF and Malaysian MP?

\subsection{DATA AND METHODOLOGY}

The population of this study consists of Malaysian manufacturers located throughout Peninsular Malaysia. Due to the fact that lean manufacturers were not listed in any databases, the selection of the sampling frame had to be based on available data from previous research in the area of lean. Based on previous research, the local industries known to implement lean are electrical and electronic, automotive and aeronautical. Therefore, the industries selected for this study comprise of electrical and electronic, automotive and aeronautical. The list of manufacturers was sourced from the FMM Directory 2010 , including the main manufacturers as well as the supporting industries. The stratified proportionate sampling method was used in this research. Based on [69], a minimum sample of 291 is an appropriate sample size for a population of 1,200 to 1,300 . However, due to the expectation of a low response rate (at around $12 \%$ ), which is common among Malaysian manufacturers, as exhibited in previous studies [62, 139], the researcherdecided to implement over sampling. A low response rate would prove to be a problem during the data analysis using SEM as at least 100 usable samples are required [23]. Therefore, in order to achieve the maximum number of usable samples, the number of questionnaires sent out was increased by $50 \%$ This method of over sampling is not new to the field of social sciences. Scholars, such as [107], have suggested the over sampling method where sample sizes are increased by $40-50 \%$ to make up for unusable responses and low response rate. [132] also stated that in such circ umstances, a larger sample would help reduce the sampling error and avoid failure to detect actual relationships in any actual given population. Based on these arguments, the researcher decided that it was justifiable to send questionnaires to all the lean ma nufacturers. Therefore, after factoring the $50 \%$ increase, the number of questionnaires sent out in this research was 437.

\subsection{MEASURING THE VARIABIES}

\subsection{Manufacturing Performance}

Manufacturing performance is best measured using both nonfinancial and financial measurement [2]. Therefore, in the context of this study, manufacturing performance was measured using both dimensions. A ten-item measurement, which was adapted from [36, $63,97,124]$, was used in this study to assess manufacturing performance. It is important to include nonfinancial measures as it broadens the spectrum of control by avoiding short- sighted measurement while financial measurement is heavily favored as it is directly linked to the outcome of the implemented strategies [36]. Nonfina ncial mea sures included ma rket share, sales growth, quality performance as well as end product/process innovation. The manufacturing perfomance measurement for this study used interval scales.

\subsection{Lean Manufacturing}

A forty-eight item measure adapted from [115, 116] was used to measure lean manufacturing. The questions measure nine dimensions that collectively and additively contribute to the forming of lean manufacturing practices. These dimensions were (1) supplier management, (2) just-in-time delivery, (3) customer involvement, (4) pull production, (5)flow production, (6)setup time reduction efforts, (7)total productive/total preventive maintenance, statistical process control, and (9)employee involvement. The respondents were asked to rate their lean manufacturing implementation level within their own manufacturing facility.

\subsection{Manufacturing Technology}

Nineteen item measures were adapted from [125] and [68] to measure the level of manufacturing technology usage by different manufacturers. Manufacturing technology is usually measured by the level of investment, level of a doption and level of benefit from implementing these strategies. However, measuring the benefit is problematic due to manager's inability to accurately gauge the benefit due to their limited knowledge of certain technologies.As for the level of investment made on the technology, even though previous scholars $[68,112]$ indicated that the performance in SMEs increased significantly with increased investment in manufacturing technology, in the context of this study it was not included due to the difference between the financial capability of MNC ma nufacturers compared to their smaller counterparts. This study foc uses on lean manufactures regardless of their size, thus measuring the manufacturers' level of investment in technology despite the different financial vigor would yield a distorted outcome. These measures were formed from four dimensions of manufacturing technology, which were grouped into information exchange and planning technology, production design technology, high volume automation technology and low volume flexible automation based on the earlier work by [125] and [68]. The respondents were asked to rate the usage of manufacturing technology for their organization within their operation.

\subsection{Strategic Rexibility}

Strategic flexibility was detemined using a fourteen items measure, adapted from [71,105,114]. In this study, the measures for strategic flexibility were 
adapted from the dimensions; namely, capacity change, process efficiency and product development. The respondents were asked to rate their organization's ability in making strategic changes within their operation.

\subsection{Extemal Environmental Factors}

To a large extent, the extemal factors of any organization determine its adopted strategy for reaping the competitive advantage $[81,90]$. Due to the vast number of environmental factors, the selection of which factor to focus on depends on the research objectives itself. In the scope of this study, dynamism and hostility a re the two dimensions used to measure the extemal environmental factors. Despite various factors, dynamism and hostility are the two most measured factors in va rious business environment studies [82, 88, 138]. Extemal environmental factors were measured using twelve items, adapted from $[8,29,71,79,86,76]$. In this study, the measures of environmental factors were adapted from its dimensions, i.e. dynamism and hostility. Summation of hypothesestested in the study were:

H1: A lower level of extemal environmental factors positively impacts manufacturing performance.

H2a: A lower level of extemal environmental factors negatively impacts lean manufacturing implementation.

H2b: A lower level of extemal environmental factors negatively impacts manufacturing technology implementation.

$\mathrm{H} 2 \mathrm{C}$ : A lower level of extemal environmental factors negatively impacts strategic flexibility

H3a: Higher lean manufacturing implementation will positively affect manufacturing performance

H3b: Higher strategic flexibility implementation will positively affect manufacturing performance.

$\mathrm{H} 3 \mathrm{c}$ :Higher manufacturing technology implementation will positively affect manufacturing performance.

\subsection{RESULTS}

The respond rate was at $19.4 \%$, where all the respondents were from the $E \& E$ and automotive sectors, with no response from the aeronautical industry being received. Collected data was analyzed using SmartPLS.

\subsection{Quality of Measurement Model}

As suggested by [50], 0.5 was used as the minimum value for significant loadings. As the measurement items for this study were based on previous studies and had been tested before, with a strong showing of instrument validity value, 0.5 was chosen and used as the minimal cutoff point for factor loadings. Examining the loadings for each of the seven constructs; out of 103 items, 14 had loadings of less than 0.5 , and, thus, were eliminated. In total, $13.6 \%$ of the items were taken out during measurement model validation. All of the remaining elements met the 0.5 threshold, signifying that the measures were adequate in their validity individually. The composite reliability for all constructs, is more than 0.7 , and, thus, is reliable, while all of the average variance extracted (AVE) was greater than the recommended 0.50 level. Thus the measurement model is deemed valid and reliable for this research.

\subsection{Structural Model}

Given the adequate measurement model, the hypotheses of the study could be tested by examining the structural model. Mediation studies using PLS consist of several altemative approaches, and, for the purpose of this research, the researcher chose the bootstrapping approach. The research framework for this structural model consisted of five va riables namely independent variable i.e. EEF, mediating variables, which are LM, SF and MT; and lastly dependent variable i.e. MP. The following Figure 1 shown the structural model tested.

Figure 1 Tested model

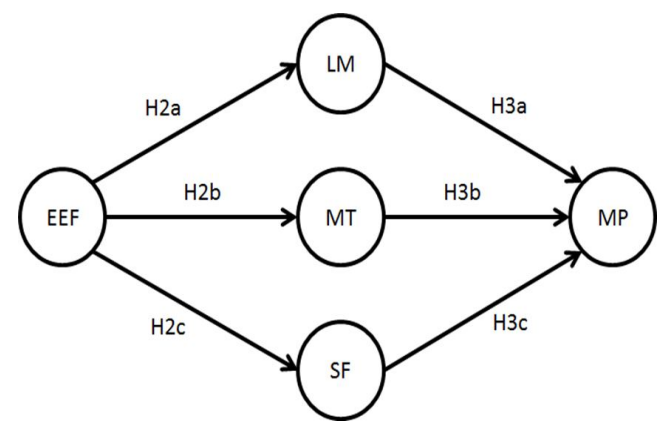

Note:

$\mathrm{EEF}=$ extema I environmental factor, MT=manufacturing technology

$\mathrm{LM}=$ Jean ma nufacturing

$\mathrm{SF}=$ stra tegic flexibility

$\mathrm{MP}=$ manufacturing performance 
Meanwhile, Table 2 shown the result for hypothesestested.

\begin{tabular}{llllll}
\hline Hypothesis & Path & Beta & $\begin{array}{l}\text { Standard } \\
\text { Enor }\end{array}$ & tvalue & Decision** \\
\hline H1 & EEF--MP & 0.301 & 0.079 & 3.793 & Supported \\
H2a & EEF-LM & -0.280 & 0.157 & 1.781 & Supported \\
H2b & EEF-SF & -0.477 & 0.098 & 2.280 & Supported \\
H2c & EEF--MT & 0.224 & 0.127 & 3.536 & Supported \\
H3a & LM--MP & 0.338 & 0.107 & 3.163 & Supported \\
H3b & SF-MP & -0.206 & 0.071 & 9.207 & Supported \\
H3c & MT--MP & 0.657 & 0.120 & 1.716 & Supported \\
\hline
\end{tabular}

\subsection{Calculation of $\mathbf{R} 2$ and Predictive Relevance of the Model}

The $R^{2}$ value is one of the methods that can be used to predict model accuracy in which a higher value of $R^{2}$ means a higher level of predictive accuracy. The model showed $\mathrm{R}^{2}$ value of 0.53 with predictive relevance of $\mathrm{Q}^{2}>0$. This result showed that the model managed to explained more than $50 \%$ of variance in manufacturing performance and $\mathrm{Q}^{2}>0$ implied that the model has predictive relevance.

\subsection{DISCUSSION}

In this research, the results indicated that a higherlevel of extemal environmental factors represented by dynamism and hostility causes a lower level of manufacturing perfomance. The perfomance was measured by both financial and nonfinancial measures. As anticipated, this finding was consistent with the earlier works of [93] and [64]. The findings from this research further cemented the work of [124], who stressed that environmental factors play a signific ant role in fim perfomance. Earlier researchers, such as [135], who also studied the relationship between environmental dynamism and environmental hostility, mentioned the existence of mediators in the form of manufacturing strategy and operation strategy. In an environment perceived to be threatening to the organization and the operation of any manufacturers, the affected manufacturers would have to react swiftly in order to maintain survival and ensure future prosperity. One of the main paths taken by manufacturers was through the realignment, readjustment and rethinking of their manufacturing strategy.
9.1 Complementarity Effect of Multiple Manufacturing Strategies

Lean as a strategy has long been recognized by prominent operation gurus and well established manufacturers, such as Toyota. Toyota's lean manufacturing was bom out of troubled economic times after World Warll. At one point, in 1948, Toyota's cash flow was so severely affected that its debt was eight times more than its total capital [77]. In order to a void banknuptcy, Toyota adopted a very strict cost cutting policy, which included staff pay cuts, the laying off more than 1,600 workers and, eventually, the resignation of its prominent leader Kichiro Toyoda. In the 1950s, Keiichin's cousin Eiji Toyoda and Toyota's plant manager Taiichi Ohno started to work on reinventing manufacturing after Eiji's tour of Americ an manufacturers. Expecting to see advanced manufacturing facilities and techniques, he was sumprised to discover that mass production still dominated the US and no significant progress had happened since the 1930s. Upon retuming, Eiji asked Ohno to come up with a system that was more efficient and could at least match Ford's mass production rate. Starting from the shop floor, Ohno began to apply the principles of jidoka and one-piece flow. Inspired by the concept of supemarkets, Ohno added the 'pull system' and included the idea of kanban inventory. Jidoka is the principle of building quality into the product. The combination of kanban and the 'pull system' produced the just-in-time (JIT) system. JIT is a set of principles, tools, and techniques that allowed Toyota to make and deliver products in small quantities, with a short lead time, to meet the quality requirements of the customer [77]. The strategy became even more discemible and spread globally when the oil crisis hit in 1973, which caused global recession [77]. Notably, lean manufacturing continued 
to progress, and, in the 1990s, the global business community finally realized that focusing on quality will actually reduce cost more significantly than focusing on cost itself. Based on empinical proof provided by scholars such as $[4,108,110]$, lean manufacturing undoubtedly fulfills the criteria of being a manufacturing strategy and has been deemed invaluable as it contributes positively to manufacturers performance.

However, the implementation of lean production itself is complex. The system requires additional tools and technologies [53, 56,137] and implementation guidelines or implementing handbooks a re not readily available for interested companies. Therefore, in trying to implement lean, companies have no knowledge about the importance of the respective complementary strategies, such as manufacturing technologies, and rely solely on the opinions of experts [74], which might or might not work for their specific plants and operations. The importance of adding technology to the lean system cannot be avoided, as to cope better with the unc ertainties and disuptions in the dynamic market environment, more intelligent and flexible manufacturing systems are needed, a huge challenge, especially for the companies in which tooling and equipment require large capital investment $[27,64,123]$. Given the advantage of being flexible through automation, lean manufacturers should be able to respond to changes more effectively if strategic plans are properly developed ahead of their absolute need. In respect of the findings from this research, Malaysian lean manufacturers cautiously approach the addition of manufacturing technology to their lean system. In contrast, an increase in dynamism and hostility surrounding the manufacturers does not suggest an increase in the implementation of manufacturing tec hnology in their system.

Such a suggestion could be due to several factors, such as the high cost of investment involved in orderto implement manufacturing technology. Thus, such a strategic choice cannot be handled lightly as a shortterm stop gap measure because it poses a risk of failure that could be detrimental to the financial wellbeing of manufacturers; therefore, it requires careful planning and investigation prior to application. As suggested by [89], the key to the successful introduction of automation to the lean system is choosing the right technology to be implemented in the production.

The crucial aspect is the strategy of the Malaysian manufacturer in selecting and adopting suitable manufacturing technology to maximize the benefits, and to recoup the huge investment involved in its implementation. Another factor that could explain the cautious approach by the Malaysian manufacturers toward manufacturing technology is the nature of the lean manufacturing concept itself. Lean manufacturing focuses more on laborcreativity before tuming to automation for a solution [89]. The basic concept of lean is to ensure that no waste is incomorated in the production system. Thus, deciding to include manufacturing technology as part of such a system would call for not only fina ncial justific ation but operational justification of whether such an addition would result in an increase in efficiency or an increase in the production process, and deciding whether the inclusion would cause a more elaborate process and thus prove wasteful. Lean manufacturers such as Toyota do incorporate automation in their production, which includes an a utomated poka yoke and flexibility enhancement machines, which could offer a faster solution to the production issue.

However, such 'frugal' incorporation is justifiable when its addition increases the flexibility and escalates the ability of production to support customized products with a lower changeover cost. The lean concept also stresses high autonomy for the production line workers and that they are responsible for the processes and products that go through their stations. Thus, by including automation into the mix, higher skilled operators are needed to operate such an addition in the process line. Training is required for these operators in order for them to handle this extra responsibility, and demanding more resources and support from the manufacturers in order to produce higher skilled workers, which again raises the issue of whether additional mechanization would provide leverage for lean manufacturers to make such an attempt.

However despite the cautious approach in the implementation of manufacturing technology at their plants, Malaysian lean manufacturers have exhibited confidence in the impact of such implementation. In parallel to previous research namely $[1,68,87,100,129]$ manufacturing technology has been shown to have a positive impact on enhancing the perfomance of manufacturers, by strengthening the structural aspect of the organization. Accordingly, Malaysian manufacturers continue to demand the latest technologies, which amounts to a staggering value of RM30 billion annually [22, p.45]. Most of these technologies are acquired from various countries overseas [1]. Malaysia continues to remain a crucial importer of machinery equipment, and, by 2013 , such investment amounted to RM35 billion.Such an astronomical figure indicates how despite the associated high risk and high financial obligation of investing in manufacturing technology, Malaysian manufacturers continue to use it as a strategic choice in order to continue gaining momentum in this competitive business environment.

Provisional to strategic flexibility, this study suggested that ma nufacturers in Malaysia tend to adopt strategic flexibility when there is a higher level of dynamism and hostility in the environment. However, interestingly, such a complementary effect was not observed due to the ensuing result, which indicated that an inc rease in strategic flexibility did not enhance manufacturing 
performance, unlike the two other two strategies. In defining flexibility, emphasis on the level of flexibility must be considered [43]. By means of definition, flexibility is the ability of any organization to react to changes surrounding their operation. The reaction could either be offensive or defensive, as shown in this research. Flexibility has always been linked to environmental uncertainty, comprising elements that include (but not limited to) agility, adaptability and robustness. The level of flexibility could be as low as operational flexibility, such as an individual production line or specific machinery, or could be as high as comorate level, which includes expansion, market penetration as well as plant capacity flexibility. Based on the studies of past researchers $[33,37,51,92,105$, 124], the implementation of flexibility at the strategic level always results in an increase in perfomance and manufacturers choose to incorporate various types of flexibility in order to remain agile and responsive to any changes in the environment. The result of this research, however, suggests otherwise.

The outcome from this research implies that from the standpoint of lean manufacturers in this study, strategic flexibility could in fact negatively influence manufacturing performance. This result is clearly different from the earlier outcomes of previous research on strategic flexibility and manufacturing performance. Strategic flexibility was measured in this study through three different dimensions - change in capacity, process efficiency and product development. Closer inspection on the entity of this study was done in order to explain the relevance of such a finding. The most obvious element of the research was the fact that, demographically, $70 \%$ of respondents in this study consisted of multinational comorations (MNCs) and joint venture companies. Previous research on MNCs and joint venture companies in Malaysia revealed that these business units serve as subsidiaries to headquarters $(\mathrm{HQ})$ or parent companies, located overseas. The relationship of subsidiaries to their HQ's varies among companies, but, notably, in some aspects, overlaps, such as the degree of control mechanisms put in place by the HQ. There a re many types of control mechanism, one such being the control of decision making or a utonomy. The degree of autonomy given to subsidiaries in respect of several aspects, such as the development of the product itself [140], the strategic sensitiveness of knowledge-related activities [14, 85] and responsiveness toward a long-tem strategic approach [32] have long been found to be inadequate. Although these groups of manufacturers recognized the importance of proper integration in their multinationals in order to be flexible, implementing it is not as straight forward and simple. Previous research $[39,91]$ on local MNCs and JVs indicated how regardless of these operating plants being located in Malaysia, major changes involving innovation and approaches to various strategic blueprints and decisions are still being coordinated, commanded and controlled by their $\mathrm{HQs}$. From the perspective of these locally located companies, they are given the responsibility to manufacture goods as directed, and, most of the time, local managers are not being involved by their HQs in terms of long-term planning and decision-making. The findings from this research support the notion that local manufacturers could have focused more on the short-tem perspective, and neglecting the long-tem (strategic) approach at the plant level. The responsibilities of local manufacturers are confined to implementing manufacturing strategies that involve order completion and cost reduction. Local managers hardly ever have the time or opportunity to contribute to strategic planning and decision-making. The research findings concur with the previous research involving Malaysian manufacturers conducted by [32], in which it was shown how the factual prionities of the managers of local manufacturers are more inclined toward meeting short-term goals. Emphasis was mostly on operational flexibility at the plant, based on meeting production capacity and optimizing the production lines to serve the manufacturers better in contributing toward order fulfillment and cost reduction. This could be one of the reasons why local manufacturers focus intensely on meeting customer orders instead of being actively involved in any strategic planning activities. Several other studies on Malaysian MNCs also corroborate how HQ provides support in the form of consultants [91] while still exclusively retaining strategic decisionmaking and planning within the jurisdiction of the parent company [39]. Similarly, there is also the possibility that Malaysian manufacturers view new processes or products as potentially disuptive to the current established products and processes. In other words, manufacturers might consider major changes that come with the introduction of new products or processes or sources of raw material as arduous as it requires the manufacturing system to adapt to 'new' elements, which, in tum, could reduce the perfomance of routine operations, whilst disnupting the existing stability of 'in house' production. Such disnuption could cause these manufacturers to fail to attain their objectives, such as targeted order completion, assigned production lead time, and, in due course, delay the delivery of products to the customers. This outc ome is similar to that reported by [10] in which flexibility was viewed as a trade-off for efficiency during model changeover at the Toyota plant itself, especially when the human resources involved lack the necessary knowledge and skill to handle it properly.

Another issue that might clarify this finding is the level of flexibility measured in this research and the overall focus of local lean manufacturers. While manufacturers prefer operation flexibility, strategic flexibility is the outcome of the cumulative operation level flexibility that impacts the long-term goal of the companies. Apart from being a potent tool against handling environmental challenges, strategic flexibility ensures that the manufacturers operate as optimal cost producers instead of the lowest cost producer to 
the market. However, as lean producers, these manufacturers might have made various changes by eliminating waste and increasing value throughout their process; again the attention being on the operation where process optimization remains as the main core target of production. Therefore, clearly the focus of locally located manufacturers remains on their ability to achieve plant level targets as lean manufacturers instead of the overall strategic goals of the global focused HQs. A similar inclination of Malaysian manufacturers toward operational flexibility in meeting customer demands was also observed in an ea rier study by $[9,141]$. Hence, while implementing these required flexibility elements in their operations, as required by the $\mathrm{HQs}$, local lean manufacturers in this study were unable to disting uish the positive impacts of these elements on their perfomance. Thus, as exhibited in the outcome of this research, such strategic level flexibility was viewed as detrimental to the overall manufacturing perfomance by these Malaysian lean manufacturers.

\section{CONCLUSION}

This study reveals the signific ant impact of the extemal business environment on the Malaysian manufacturing sector and the consequences if the manufacturers a re not able to react strategically thereto. The importance of the contribution of the manufacturing sector to the Malaysia economy remains the main reason why the researcher chose to embark on this study. Based on the previous negative impact from the unsettled global economy that presented manufacturers various challenges to their operational stability, manufacturers have no choice but to figure out the best and most fitting way to protect their intemal core from the effects of the extemal factors. It outlines the strategy-performance model for Malaysian lean manufacturers.

This research also reveals how multiple manufacturing strategies could help manufacturers to overcome and cushion the aforementioned challenges in order to stay competitive and remain profitable. However, from the perspective of manufacturers, choosing the right strategy is also crucial and contingent to the threats they face. This research model shows how important it is to decide which strategy to choose in order to protect their operation and yet remain competitive enough to be cost effective and profitable in the long-run. One thing for sure, heavy dependence on global trade is una voidable as Malaysian manufacturers continue to expand their standings in the global market. Most previous research in the area of manufacturing took the traditional approach of choosing a 'stance' or any type of manufacturing strategy to adhere to, upon which the operation of the company would be based. Although this type of approach does work, the rigidity limits its expansion and customization, which has prevented it from being holistic enough to be embraced in totality for a long time. Due to the ever changing conditions of the extemal environmental factors, a rigid approach to how any fim should react to these changes would be detrimental to the company. The researcher acknowledges that while changing strategies frequently is not the answer, neither is stic king to strategies that do not work. Due to such an argument, and the wide variety of types of manufacturing, manufacturers should be able to pick and choose the strategies that best suits them. This is why the content approach to manufacturing strategy is suitable. By looking at what is actually a vailable and best suited to its core operation requirement, manufacturers would be able to specifically customize their manufacturing strategy according to the needs and requirements of their extemal and intemal operational needs. At the end of the day, such a choice should be to help manufacturers perform better and yield more profit irespective of the challenges that come their way. While the govemment rigorously continues to establish an ideal manufacturing environment in tems of building more infrastructure in manufa cturing zones a round Malaysia, upgrading the transportation system, providing incentives to encourage the training of skilled workers, etc., at the end of the day, the manufacturers themselves must develop the capability to operate in a very dynamic environment and thus take charge to compete globally.

In addition, this research also disclosed the trait of lean manufacturers when it comes to complementary strategies within their operation. The literature pointed out how several implemented strategies would be complementary to each other and add value to the overall composition of the strategies used. Here, the study brought to light how lean manufacturing and manufacturing technology help mediate the impact of extemal challenges and increase manufacturing perfomance. The tested model provides a good understanding of the factors that explain manufacturing performance with high predictability value and high variance. The combination of all three manufacturing strategiesmanaged to explained more than half of the manufacturing performance variance, thus indicating how when implemented together these three strategies can significantly affect the outc ome of lean ma nufacturers perfomance.

In conclusion, the study of manufacturing strategymanufacturing performance should continue to receive complete and substantial attention from manufacturing based researchers. In relation to the increasing global changes that provide both opportunities and threats, the study will prove to be crucial to the overall dynamic of Malaysia's economy and well-being. Given the critical impact of manufacturing perfomance on Malaysia's economy, it is the hope of the researcher that this study sheds some light on the enablers of high performing manufacturing systems so that future research could explore the subject more rigorously and comprehensively. 


\section{SUG GESTION FOR FUTURE RESEARCH}

The results suggest that future research would be helpful to provide a deeper understanding of Malaysian manufacturing strategies and their performance in dealing with extemal business threats and challenges. This research clearly indicates that there is more ground to explore, investigate and understand in the area of manufacturing perfomance. As it is obviously vital to the well-being of the nation's economy, manufacturing perfomance should remain the core of scholarly research. In tems of measuring the performance, future research should focus on the wider dimension of future measurement to ensure it will be able to capture and provide a more thorough and case sensitive measurement tool for manufacturing perfomance. New elements, such as innovation capability; supply chain flexibility; dynamic capability; as well as environmental indicators, such as green manufacturing, should be considered as part of the manufacturing perfomance in future research.

In addition, future research should also consider additional manufacturing strategies to be included as part of the research framework. While three strategies were included in this research, with the continual advancement made in the application of structural equation modeling, more complicated models could be tested in the future. Strategy studies are very complicated and can sometimes appear arbitrary, References

[1] Abd Rahman A, Bennett D J .2009. Advanced manufacturing technology adoption in developing countries: The role of buyer-supplier relationships. J oumal of Manufacturing Technology Management, 20 (8), pp. 10991118.

[2] Abdel-Maksoud A, Dugdale D, Luther R .2005. Non-financial performance measurement in manufacturing companies. The British Accounting Review, 37(3), pp. 261-97.

[3] Abdallah A B, Matsui Y .2007. JIT and TPM: Their relationship and impact on JIT and competitive performances. Paper presented at the Conference of the Intemational Decision Sciences Institute (DSI), Bangkok, Thailand.

[4] Ahmad S, Schroeder R, Sinha K.2003. The role of infrastructure practic es in the effectiveness of JIT practices: Implic ations for plant competitiveness. Joumal of Engineering and Technology Management, 20, pp. 161-191.

[5] Ahmed N U, Montagno R V, Firenze R J .1996.) Operations strategy and organizational performance: an empirical study. Intemational Joumal of Operations and Production Management, 16(5), 41-53.

[6] Ahmad A, Mehra S, Pletcher M .2004. The perceived impact of JIT implementation on fims' financial/growth performance. Joumal of Manufacturing Technology Management, 15 (2), pp. 118-130.

[7] Al-Yousif $Y K$.1999. On the role of exports in the economic growth of Malaysia: A multivariate analysis. Intemational Ec onomic Joumal, 13, pp. 67-75.

[8] Anand G, Ward P T.2004. Fit, flexibility and performance in manufacturing: coping with dynamic environments. Production and Operations Management, 13 (4), pp. 369385.

[9] Anuar A, Yusuff R M .2011. Malaysia best practices in Malaysian small and medium enterprises (SMEs). Benchmarking: An Intemational J oumal,18(3), pp 324-341. especially with a wider and deeper choice of new approaches to the concepts. Therefore, more complicated models are likely to appear soon on the horizon and require empirical proof.

Lastly, future research should also look into enlarging the scope of this study to inc rease the generalizability of the research outcome. Widening the area of focus to include as many manufacturers as possible will provide better and more representative data. Apart from larger industry involvement, respondents from the manufacturers should also include operation level workers that camy out and practice hands on manufacturing strategy; however, the inclusion of managerial and executives should still be included in order to ensure the strategic level data will also be captured. These two approaches will ensure a complete encapsulation of the perspective from the manufacturers. The existence of quasi-paradoxical variables further indicates that a longitudinal study would be encouraged to further investigate the nature of such relationships.

[10] Amsden A H .1989. Asia's next giant: How Korea competes in the world economy. Technology Review, 92(4), pp. 46-53.

[11] Amsden, A H, Chu Wu-wen.2003. Beyond Late Development: Taiwan's Upgrading Policies: Vol. 1. London: The MITPress.

[12] Ballé M .2005. Lean attitude - Lean application often fail to deliver the expected benefit but could the missing link for successful implementations be attitude?. Manufacturing Engineer, 84, pp. 14-19.

[13] Bames-Schuster D, Bassok Y, Anupindi R.2002. Coordination and flexibility in supply contracts with options. Manufacturing and Service Operations Management, 4(3), pp. 171-207.

[14] Bartlett C A, Goshal S .1989. Managing Beyond Borders. Boston: Harvard Business School.

[15] Beach R, Muhlemann A P, Price D H R, Paterson A, Sharp J A 2000. A review of manufacturing flexibility. European J oumal of Operational Research, 122, pp. 41-57.

[16] Bemy W L, Christiansen T, Bruun P, Ward P .2007. Lean manufacturing: A mapping of competitive priorities initiatives, practices, and operational performance in Danish manufacturers. Paper presented at the Anais do 14 Intemational EurOMA Conference, Ankara.

[17] Bhasin S, Burcher $P$.2006. Lean viewed as a philosophy. Joumal of Manufacturing Technology Management, 17(1), pp. 56-72.

[18] Bordoloi, S K, Cooper W W, Matsuo, H .1999. Flexibility, adaptability, and efficiency in manufacturing systems. Production and Operations Management, 8(2), pp. 133-150.

[19] Boyle T A .2006. Towards best management practices for implementing manufacturing flexibility. Joumal of Manufacturing Technology Management, 17 (1), pp. 6-21.

[20] Brown S, Blackmon K .2005. Aligning Manufacturing Strategy and Business-Level Competitive Strategy in New Competitive Environments: The Case for Strategic Resonance. Joumal of Management Studies, 42(4), pp. 793-815.

[21] Burcher P G, Lee G L, Sohal A S .2004. The changing roles of production and operations managers in Britain from the 
1970s to the 1990s. Intemational J oumal of Operations and Production Management, 24(4), 409-423.

[22] Business Times .2006. Kuala Lumpur, Business Times, 24 April. P. 45.

[23] Byme B M .2010. Structural equation modeling with AMOS: Basic concepts, applications, and programming. (2nd ed.). New York: Routledge Academy.

[24] Callen J, Fader C, Kimksky I .2000. Just-in-time: A crosssectional plant analysis. Intemational J oumal o Production Economics, 63, pp. 277-301.

[25] Callen J .2010. Innovation for HIMJ: The launch of the Intemational Advisory Panel. Health Information Management J oumal, 39(1).

[26] Chen H, Lindeke R R, Wyrick D A .2010. Lean automated manufacturing: Avoiding the pitfalls to embrace the opportunities. Assembly Automation, 30 (2), pp. 117-123.

[27] Chin W W .1998. Commentary: Issues and opinion on struc tural equation modeling. MISQ uarterly.

[28] Choong C K, Zulkomain Y, Khim-Sen V L .2003. Export-led growth hypothesis in Malaysia: An application of two-stage least square technique (Working Paper No.0308002). Intemational Finance, EconWPA.

[29] Covin J G, Slevin D P.1989. Strategic management of small fims in hostile and benign environments. Strategic Management J oumal, 10, pp. 75-87.

[30] Cua K O, McKone K E, Schroeder R G .2001. Relationships between implementation of TQM, JIT and manufacturing performance. Joumal of Operation Management, 19, pp. 675-694.

[31] Das TK, Elango B .1995. Managing strategic flexibility: key to effective performance. Joumal of General Management, 20, pp. 60-60.

[32] Dekkers R, Kanapathy K .2012. Practices for strategic capacity management in Malaysian manufacturing fims. Procedia-Social and Behavioral Sciences, 57, pp. 466-476.

[33] De Meyer A, Nakene J, Miller J, Ferdows K .1989. Flexibility: the next competitive battle. Strategic Management Joumal, 10, pp. 135-144.

[34] De Toni A, Tonchia S .1998. Manufacturing flexibility: A literature review. Intemational Joumal of Production Research, 36 (6), pp. 1587-617.

[35] De Toni A, Tonchia S.2005. Definitions and linkages between operational and strategic flexibilities. Omega, $33(6)$, pp. 525 540.

[36] Dossi A, Patelli L .2010. You leam from what you measure: Financial and nonfinancial performance measures in multinational companies. Long Range Planning, 43, pp. 498526.

[37] D'Souza D E, Williams F P .2000. Towards a taxonomy of manufacturing flexibility dimensions. Joumal of Operations Management, 18(5), pp. 577-593

[38] Easterly W, Roumen I, J oseph E S .2001. Shaken and stired: Explaining growth volatility. In B. Pleskovic and N. Stem (Eds.) Annual World Bank Conference on Development Ec onomics. Washington: The World Bank.

[39] Edwards R, Ahmad A, Moss S.2002. Subsidiary autonomy: The case of multinational subsidiaries in Malaysia. Joumal of Intemational Business Studies, pp. 183-191.

[40] Flynn B B, Schroeder R G, Sakakibara S .1995. The impact of quality management practices on performance and competitive advantage. Decision Sciences, 26 (5), pp. 659691.

[41] FMM DIRECTORY .2010.Electric al and Electronics. 41st. FMM Direc tory Malaysia.

[42] Germain R, Claycomb C, Dröge C .2008. Supply chain variability, organizational structure, and performance: The moderating effect of demand unpredictability. Joumal of Operations Management, 26 (5), pp. 557-570.

[43] Gerwin D .1987. An agenda for research on the flexibility of manufacturing processes. Intemational Joumal of Operations and Production Management, 7 (1), pp. 38-49.

[44] Gerwin D .1993. Manufacturing flexibility: A strategic perspec tive. Management Science, 39 (4), pp. 395-410.
[45] Gerwin D .2005. An agenda for research on the flexibility of manufacturing processes. Intemational Joumal of Operations and Production Management, 25 (12), pp. 11711182.

[46] Gindy N N, Cerit B, Hodgson A .2006. Technology road mapping for the next generation manufacturing enterprise. Joumal of Manufacturing Technology Management, 17(4), pp. 404-416.

[47] Gouvea Da Costa S E, Platts K W, Fleury A .2006. Strategic selection of advanced manufacturing technologies (AMT), based on the manufacturing vision. Intemational J oumal of Computer Applications in Technology, 27 (1), pp. 12-23.

[48] Goyal M, Netessine .2007. Strategic technology choice and capacity investment under demand uncertainty. Management Science, 53(2), pp. 192-207.

[49] Gupta Y P, Goyal S .1989. Flexibility of manufacturing systems: concepts and measurements. European J oumal of Operational Research, 43 (2), pp. 119-135.

[50] Hair J F, Black W C, Babin B J, Anderson R E, Tatham R L 2010. Multivariate data analysis (7th ed.). New Jersey: Prentice Hall.

[51] Hallgren M, Olhager」 .2009. Lean and agile manufacturing: Extemal and intemal drivers and performance outcomes. Intemational Joumal of Operations and Production Management, 29 (10), pp. 976-999.

[52] Hamid Z .2010. Concentration of exports and pattems of trade: A time-series evidence of Malaysia. The Joumal of Developing Areas, 43(2), pp. 255-270.

[53] Hamis R, Hamis C .2008. Can automation be a lean tool. Manufacturing Engineering Magazine. Vol. 141, No. 2.

[54] Hayes R H, Wheelwright S C .1985. Restoring our competitive edge: Competing through manufacturing. New York, NY: Wiley.

[55] Hayes R H, Pisano G P .1994. Beyond world class: The new manufacturing strategy. Harvard Business Review, 72, pp. 77 84.

[56] Hedelind M, Jackson M .2011. How to improve the use of industrial robots in lean manufacturing systems. Joumal of Manufacturing Technology Management, 22(7), pp. 891-905.

[57] Hill C W.1985.Diversified growth and competition :The experience of twelve large UK firms. Applied Economics, 17 (5), pp. 827-847.

[58] Hilman H, Mohamed Z A .2011. Building new competitive advantage through match between specific types of strategic flexibility and sourcing strategy. Joumal for Global Business Advancement, 4(4), pp. 356-367.

[59] Hutchison J, Das SR .2007. Exa mining a fim's decisions with a contingency framework for manufacturing flexibility. Intemational Joumal of Operations and Production Management, 27 (2), pp. 159-180.

[60] Jacobs P .2005. Five Steps to Thriving in Times of Uncertainty, Harvard Business School Publishing Corporation.

[61] Joseph M, McClure C, Joseph B .1999. Service quality in the banking sector. the impact of technology on service delivery. Intemational J oumal of Bank Marketing, 17 (4), pp. 182-193.

[62] Jusoh, R. .2007. The use of multiple performance measures among the balanced scorecard adopters and nonadopters: Evidence from the Malaysian manufacturers. Paper presented at the Intemational Conference on Global Research in Business and Economics, 27-29 December 2009, Bangkok, Thailand.

[63] Jusoh, R. .2010. The influence of perceived environmental uncertainty, fim size, and strategy on multiple performance measures usage. African J oumal of Business Management, 4 (10), pp. 1972-1984.

[64] Kabadayi S, Eyuboglu N, Thomas G P .2007. The performance implications of designing multiple channels to fit with strategy and environment. J oumal of Marketing, 71 (10), pp. 195-211.

[65] Ketokivi M A, Schroeder R G .2004. Perceptual measure of perfomance: Fact of fiction. Joumal of Operation Management, 22 (3), pp. 247-264. 
[66] Kestigian M .2005. Food Companies Urged to Harvest Flexibility, Manufacturers' Monthly (August), Reed Business Information Australia Ltd.

[67] Kose M, Ayhan E, Prasad S, Terrones M .2003. Financial integration and macroeconomic volatility. IMF Staff Papers, 50, pp. 119-142.

[68] Kotha S, Swamidass P M .2000. Strategy, advanced manufacturing technology and performance: Empirical evidence from US manufacturing fims. J oumal of Operations Management, 18, pp. 257-277.

[69] Krejcie R V, Morgan D W .1970. Determining sample size for research activities. Educational and Psychological Measurement, 30, pp. 607-610.

[70] Kristianto Y, Ajmal M, Tenkorang R A, Hussain M .2012. A study of technology adoption in manufacturing fims. Joumal of Manufacturing Technology Management, 23 (2), pp. 198211.

[71] Lau R S M (1996) Strategic flexibility: A new reality for worldclass manufacturing. S.A.M Advanced Management Joumal, 61 (2), pp. 11-15.

[72] Larso D, Doolen T, Hacker M .2009. Development of a manufacturing flexibility hierarchy through factor and cluster analysis: The role of new product type on US electronic manufacturer performance. Joumal of Manufacturing Technology Management, 20 (4), pp. 417-441.

[73] Lewis M .2000. Lean production and sustainable competitive advantage. Intemational Joumal of Operations and Production Management, 20(2-14).

[74] L X, Gu X J, Liu Z G .2009. A strategic performance measurement system for fims across supply and demand chains on the analogy of ecological succession. Ecological Ec onomics, 68(12), 2918-2929.

[75] Liang H S, Abdul Ghani J, Jusoh Z, Chin W .2011. A Study of the trade performance of Malaysia and its major trading partners. Joumal of The Department Of Statistics, 1, pp. 2142.

[76] Liao K, Tu Q .2008. Leveraging automation and integration to improve manufacturing performance under uncertainty: An empirical study. Joumal of Manufacturing Technology Management, 19 (1), pp. 38-51.

[77] Liker] K .2004. The Toyota way: 14 management principles from the world's greatest manufacturer. New York: McGrawHill.

[78] LikerJ K.2006. The Toyota way fieldbook. ESENSI.

[79] indeke R R, Wyrick D W, Chen H .2008. Effecting change and innovation in a highly automated and lean organization: the Temporal Think Tank ${ }^{T M}\left(\mathrm{T3}^{\mathrm{TM}}\right)$. In Proceedings of the Flexible Automation and Intelligent Manufacturing. Presented at the 18th Intemational Conference on Flexible Automation and Intelligent Manufacturing (FAIM), Skövde, Sweden.

[80] Uoréns-Montes F J, Molina L M, Verdú-jover A J .2005. Flexibility of manufacturing systems, strategic change and performance. Intemational Joumal Production Economics, 98, pp. 273-289.

[81] Lotayif M S M A M .2010. Porter's generic strategies and environmental scanning techniques: Evidence from Egypt. The Business Review Cambridge, 16 (2), pp. 216-225.

[82] Lumpkin G T, Dess G G .2001. Linking two dimensions of entrepreneurial orientation to firm performance: The moderating role of environment and industry life cycle. Joumal of Business Venturing, 16 (5), pp. 429-451.

[83] Mclvor, R. .2008. What is the right outsourcing strategy for your process?. European Management Joumal, 26 (1), pp. 24-34.

[84] Marin-Garcia J A, Garcia-Sabater J J, Bonavia T .2009. The impact of Kaizen events on improving the performance of automotive components' first-tier suppliers. Intemational Joumal of Automotive Technology and Management, 9 (4), pp. 362-376.

[85] Martinez J I, Jarillo J C .1991. Coordination demands of intemational strategies. Joumal of Intemational Business Studies, pp. 429-444.
[86] Miller D .1992. The generic strategy trap. J oumal of Business Strategy, 13 (1), pp. 37-41.

[87] Monge C A M, Rao S S, Gonzalez M E, Sohal A S (2006) Performance measurement of AMT: a cross-regional study. Benchmarking: An Intemational I oumal, 13(1/2), pp. 135-146.

[88] Moreno A M, Casillas ] C.2008. Entrepreneurial orientation and growth of SMEs: A causal model. Entrepreneurship Theory and Practice, 32(3), pp. 507-528.

[89] Morey B .2008. Product development gets leaner. Product Management, pp. 22-25.

[90] Murray A I .1988. A contingency view of Porter's generic strategies. Academy of Management Review, 13, pp. 390400.

[91] Muslimen R, Mohd Yusof S, Zainal Abidin A S .2011. Lean manufacturing implementation in Malaysian automotive components manufacturer. A Case Study. In Proceedings of the World Congress on Engineering. Paper presented at the World Congress on Engineering 2011, 6-8 July, Imperial College London, London, UK.

[92] Nakane J, Hall R W .1991. Holonic manufacturing: flexibility The competitive battle in the 1990s. Production Planning and Control, 2 (1), pp. 2-13.

[93] Nandakumar M K, Ghobadian A, O'Regan N .2010. Businesslevel strategy and performance: The moderating effects of environment and structure. Management Decision, 48 (6) pp. 907-939.

[94] Olesen D E .1990. Six keys to commercialization. J ournal of Business Stra tegy, 11(6), pp. 43-47.

[95] Or S, Sohal A S .1999. Technology and global manufacturing: Some German Eeperiences. Management Decision, 374, pp. 356-362.

[96] Papadopoulou TC, Ozbayrak M .2005. Leaness: Experiences from the joumey to date. Joumal of Manufacturing Technology Management, 16, pp. 784-807.

[97] Papke-Shields K E, Malhotra M K .2001.Assessing the impact of the manufacturing executive's role on business performance through strategic alignment. Joumal of Operations Management, 19 (1), pp. 5-22.

[98] Rasiah R, Lin Y .2005. Leaming and Innovation: The role of market, govemment and trust in the information hardware industry in Taiwan. Intemational J oumal of Technology and Globalization, 1 (3/4), pp. 400-432.

[99] Rasiah R .2010. Are electronic firms in Malaysia catching up in the technology ladder?. Joumal of the Asia Pacific Economy, 15 (3), pp. 301-319.

[100]Raymond $L$.2005. Operations management and advanced manufacturing technologies in SMEs: A contingency approach. Joumal of Manufacturing Technology Management, 16 (8), pp. 936-955.

[101]Raynor M, Leroux X .2004. Stra tegic flexibility in R\&D: How to use project selection to prepare for unpredictable future. Industrial Resea rch Institute Inc.

[102]Reinartz W, Haenlein M, Henseler J .2009. An empirical comparison of the efficacy of covariance-based and variance-based SEM. Intemational J oumal of Research in Marketing, 26 (4), pp. 332-344.

[103]Rishel T D, Bums O M .1997. The impact of technology on small manufacturing fims. Joumal of Small Business Management, 35 (1)

[104]Roitzsch K, Hacker W, Pietrzyk U, Debitz U .2012. How do German SMEs cope with the increasing need for flexibility? Advances in Decision Sciences.

[105]Rose R C, Kumar N, Ibrahim H I .2008. The effect of manufacturing strategy on organizational performance. Performance Improvement, 47 (1), pp. 18-25.

[106]Rosenzweig E D, Roth AV., Dean J r] W .2003. The influence of an integration strategy on competitive capabilities and business performance: an exploratory study of consumer products manufacturers. Joumal of Operations Management, 21(4), 437-456.

[107]Salkind N J .1997. Exploring research (3rd ed.). New J ersey: Prentice Hall.

[108] Salvador F, Forza C, Rungtusanatham M, Choi T Y .2001. Supply chain interactions and time-related performances: 
an operations management perspective. Intemationa Joumal of Operations and Production Management, 21(4), pp. 461-475.

[109]Sanchez R .1995. Strategic flexibility in product competition. Strategic Management J oumal, 16 (1), pp. 135-159.

[110]Schroeder R G, Flynn B .2002. High performance manufacturing: Global perspective. John Wiley and Sons, Inc.

[111]Schonberger R J .2007. Japanese production management: An evolution-With mixed success. Joumal of Operations Management, 25, pp. 403-419.

[112]Schroeder D M, Congden S W .2000. Aligning competitive strategies, manufacturing technology, and shop floor skills. Production and Inventory Management J oumal, 41(4), pp. 40.

[113]Schroeder R G, Bates K A, Junttila M A .2002. A resource-based view of manufacturing strategy and the relationship to manufacturing performance. Strategic management joumal, 23(2), 105-117

[114] Sethi A K, Sethi S P .1990.Flexible manufacturing: A survey. Intemational Flexible Manufacturing Systems, 2, pp. 289328.

[115]Shah R, Ward P T .2003. Lean manufacturing: Context, practice bundles, and performance. Joumal of Operations Management, 21 (2), pp. 129-149.

[116]Shah R, Ward P T.2007. Defining and developing measure of lean production. J oumal of Operation Management, 25, pp. 785-805.

[117]Singh B, Garg S K, Sharma S K, Grewal C .2010. Lean implementation and its benefits to production industry. Intemational joumal of lean six sigma, 1 (2), pp. 157-168.

[118]Skinner W .1985. Manufacturing the formidable competitive weapon. New York: Wiley.

[119]Slack N .2005. The flexibility of manufacturing systems Intemational Joumal of Operations and Production Management, 25 (12), pp. 1190-1200.

[120]Sonntag E D .2003. Adaptation and regulation with signal detection implies intemal model. Systems Control Letters, 50 (2), pp. 119-126.

[121]Stanev S, Krappe H, Ola H A, Georgoulias K, Papakostas N, Chryssolouris G, Ovtcharova J .2008. Efficient change management for the flexible production of the future. Joumal of Manufacturing Technology Management, 19 (6) pp.712-726.

[122]Steward T A, Raman A P .2007. Lessons from Toyota long way. Harvard Business Review, 85 (7/8), pp. 74-83.

[123]Suh E S, De Weck O, Kim I Y, Chang, D .2007. Flexible platform component design under uncertainty. Joumal of Intelligent Manufacturing , 18(1), pp. 115-126.

[124]Swamidass P M, Newell W T.1987. Manufacturing strategy, environmental uncertainty and performance: a path analytic model. Management Science, 33 (4), pp. 509-524.

[125]Swamidass P M, Kotha S .1998. Advanced manufacturing technology use: Exploring the effect of the nationality variable. Intemational Joumal of Production Research, 36 (11), pp. 3135-3146.
[126]Sweeney M T .1991. The strategic management of manufacturing: from waste to haste. Paper presented at 3rd Intemational Production Management Conference on Management and New Production System, Gothenburg, Sweden.

[127]Takeuchi H, Osono E, Shimizu N .2008. Contradictions that drive Toyota's success. Harvard Business Review, 86 (6), pp. 96-104.

[128]Talib A L .2012. Business cycle diagnostics for Malaysia. J ouma l of the Department of Sta tistic s Malaysia, (2), pp.1-19.

[129]Theodorou P, Florou G .2008. Manufacturing strategies and financial performance - The effect of advanced information technology: CAD/CAM systems. O mega, 36 (1), pp. 107-121.

[130]Towill D R, Christopher M .2007. Do not lean too far-evidence from the first decade. Intemational J oumal of Agile Systems and Management, 2 (4), pp. 406-424.

[131]Verdu-J over A J, Lorens-Montes F J, Garcia-Morales V J 2006. Environment-flexibility co-alignment and perfomance: An analysis in large versus small firms. Joumal of Small Business Management, 44 (3), pp. 334-349.

[132]Vogt P W .2007. Quantitative research methods for professionals. Boston, MA: Allyn and Bacon.

[133]Vokurka R J, O'Leary-Kelly S W .2000. A review of empinical research on manufacturing flexibility. Joumal of Operations Management, 18 (4), pp. 485-501.

[134]Ward P T, Duray R, Leong G K, Chee-Chuong S .1995. Business environment, operations strategy and performance: An empinical study of Singapore manufacturers. Joumal of Operations Management, 13 (2), pp. 99-115.

[135]Ward P T, Duray R .2000. Manufacturing strategy in context: environment, competitive strategy and manufacturing stra tegy. J oumal of O pera tions Management, 18(2), 123-138.

[136]White R E, Prybutok, V .2001. The relationship between J IT practices and type of production system. Omega, 29 (2), pp. 113-124.

[137]Withers S, Garza-Reyes J A, Kumar V, Rocha-Lona L .2013. A case study improvement of a testing process by combining lean management, industrial engineering and automation methods. Intemational Joumal of Engineering and Technology, 3 (3), pp. 134-143.

[138]Wiklund J, Shepherd D .2005. Entrepreneurial orientation and small business performance: a configurational approach. Jouma I of Business Venturing, 20 (1), pp. 71-91.

[139]Wong Y C .2010. A lean manufacturing implementation framework for the Malaysian electrical and electronics industry. Doctoral dissertation, Faculty of Mechanical Engineering, Universiti Teknologi Malaysia: Skudai.

[140]Young S Tavares A T .2004. Centralization and autonomy: back to the future. Intemational Business Review, 13 (2), pp 215-237.

[141]Yusuff R M .2004. Manufacturing best practices of the electric and electronic fims in Malaysia. Benchmarking: An Intemational J oumal, 11 (4), pp. 361-9.

[142]Yusoff M .2005. Malaysian bilateral trade relations and economic growth. Intemational Joumal of Business and Society, 6 (2), pp. 55-68. 